\title{
The Ottoman Empire and Europe from the late Westphalian Order to the Crimean System: the 'Eastern Question' Revisited
}

\author{
El Imperio Otomano y Europa desde el último orden de \\ Westfalia hasta el sistema de Crimea: la "cuestión oriental" \\ revisada
}

\section{O Império Otomano e a Europa do final da Ordem Westfaliana ao Sistema da Crimeia: a 'Questão Oriental' Revisitada}

\author{
Gabriel Leanca'
}

national history at the Faculty of History, Alexandru loan Cuza University, Iași, Romania. He holds a collaborative PhD from Alexandru loan Cuza University and Bourgogne University, France. He recently edited L'entrée de la Roumanie dans la Grande Guerre. Documents diplomatiques français (28 juillet-29 décembre 1914), Paris, L'Harmattan, 2020 and he is the author of $\dot{A}$ l'ère des empires et des nations : la France et les principautés de Moldavie et de Valachie (1711-1859), t. I (1711-1789), Les Éditions Isis, coll. du Centre d'histoire diplomatique ottomane, Istanbul, 2019. ORCID : https://orcid.org/0000-00019903-7433.
DOI: 10.5752/P.2317-773X.2020v8.n4.p110

Received in: September 21, 2020

Accepted in: February 04, 2021

\section{ABSTRACT}

The 'Eastern Question' is one of the most controversial and persistent subjects in the history of international relations. This article looks at two aspects of the evolution of the relations between the Ottoman Empire and Europe. The first one focuses on the importance of the $18^{\text {th }}$ century in the emergence of the 'Eastern Question'. The second one emphasizes on several episodes that may reopen the debate on the origins of the Crimean War. Our research is an attempt to demonstrate that the 'Eastern Question' was only a piece of a larger puzzle. The more Russia was influential in world politics, the more her contribution became valuable for the stability of the international system. The idea to challenge in the early 1850 's the heritage of the $18^{\text {th }}$ century in world politics (meaning to marginalize Russia in European affairs), did not serve on the long run neither to the security of the Ottoman Empire, nor to the 'new multilateralism' put forward by Napoleon III.

Keywords: Ottoman Empire, late Westphalian international order, Eastern Question, Vienna system, Crimean War, Great Power Politics $18^{\text {th }}-19^{\text {th }}$ centuries

\section{ResUMen}

La "cuestión oriental" es uno de los temas más controvertidos y persistentes en la historia de las relaciones internacionales. Este artículo analiza dos aspectos de la evolución de las relaciones entre el Imperio Otomano y Europa. El primero se centra en la importancia del siglo XVIII en el surgimiento de la "Cuestión Oriental". El segundo enfatiza varios episodios que pueden reabrir el debate sobre los origenes de la Guerra de Crimea. Nuestra investigación es un intento de demostrar que la "cuestión oriental" era solo una pieza de un rompecabezas más grande. Cuanto más influyente se destacaba Rusia en la politica mundial, más importante sería su contribución para la estabilidad del sistema internacional. La idea de desafiar a principios de la década de 1850, la herencia del siglo XVIII en la politica mundial (es 
decir, marginar a Rusia en los asuntos europeos), no sirvió a largo plazo ni para la seguridad del Imperio Otomano, ni para el nuevo multilateralismo, presentado por Napoleón III.

Palabras clave: Imperio Otomano, orden internacional tardio de Westfalia, cuestión oriental, sistema de Viena, guerra de Crimea, politica de las grandes potencias en los siglos XVIII-XIX.

\section{ResUMO}

A 'Questão Oriental' é um dos assuntos mais polêmicos e persistentes na história das relações internacionais. Este artigo examina dois aspectos da evolução das relações entre o Império Otomano e a Europa. 0 primeiro enfoca na importância do século XVIII no surgimento da 'Questão Oriental'. O segundo enfatiza vários episódios que podem reabrir o debate sobre as origens da Guerra da Crimeia. Nossa pesquisa é uma tentativa de demonstrar que a 'Questão Oriental' era apenas uma peça de um quebra-cabeça maior. Quanto mais a Rússia se tornava influente na politica mundial, mais sua contribuição se tornava valiosa para a estabilidade do sistema internacional. A ideia de desafiar, no início da década de 1850, a herança do século XVIII na politica mundial (o que significa marginalizar a Rússia nos assuntos europeus), não serviu a longo prazo nem para a segurança do Império Otomano, nem para o novo multilateralismo apresentado por Napoleão III.

Palavras-chave: Império Otomano, ordem Westfaliana tardia, Questão Oriental, Sistema de Viena, Guerra da Crimeia, Politica das grandes potências nos séculos XVIII-XIX

\section{Introduction}

In 1853, in the eve of the war between Russia and the Ottoman Empire, which shortly after became the Crimean war, Lord John Russell rejected the secret Russian proposal to dismantle the Ottoman Empire (CRPLGCT, 1854, p. 883). He did so not only because it was impossible to implement such an arrangement without risking a continental war, but because the proposal was made after several attempts from the Russian side to gain exclusive influence at Constantinople. And it was not only the quarrel between the Latin and the Greek churches, brought to the table in May 1850 by France, that first sounded the alarm at London. As a matter of fact, the first signs appeared in 1848, at a time when Nesselrode, tsar's minister of Foreign Affairs, tried to legalize the Russian military intervention at Bucharest which put an end to revolution. As one can expect, such initiatives did not go unnoticed neither in London, nor in Paris (LEANCA, 2013). But the decision of tsar Nicholas I to assist the Habsburgs in late autumn of 1848 in their fight to regain control over their empire restrained the British from acting in the Near Eastern affairs. The latter agreed that the Russians crush the Hungarian rebellion and were reluctant to align with the French in contesting the Russian projects for the European Turkey. In the eyes of the British government, the Habsburg Empire, no matter how authoritarian the Metternich regime was perceived in Europe, was the only political entity which could, by its geographical position, neutralize or at least weaken Russia's Near Eastern policy. But with Austria depending on Russia after 1848, the British statesmen had to get over their anxieties regarding France and its global ambitions and to openly oppose Russia in the Near East.

The collapse of the Habsburg Empire in 1848 and the well-known tendency of the Russians to dominate the Ottomans were both European problems, but in a very different way. Contrary to the general view regarding 
the impact of the 1848 revolutions on the international politics (JELAVI$\mathrm{CH}, 1984$, p. 50), Russia was not able to change the status quo in its relation with the Ottoman Empire. In other words, Russia was not able to secure more treaty rights in the Ottoman Empire neither after the conclusion of the treaty of Adrianople of 1829, nor after the Saint-Petersburg Convention of 1834. The so-called Balta-Liman Convention of 1849, which should have legitimised, in Russian terms, the use of unilateral military means to crush civil unrest in Moldavia and Wallachia, did not go beyond practical arrangements respecting the administration of these two provinces. No alliance to counter Russia in the Near East was to be formed between France and Great Britain during the 1848 crisis either. However, the treaty of Adrianople and the other agreements that followed, were the absolute maximum the British and the French could accept in terms of Russian influence at Constantinople. On top of that, it was not the proposition itself which was made in 1853 to Lord John Russell that finally set the Concert of Europe on fire, but the fact that tsar Nicholas I remained adamant about securing unprecedented influence at Constantinople even after the British rejection of the scheme. A second Russian unauthorized occupation of the principalities, followed by the military preparations of the maritime powers against Russia and the violation of the Straits Convention by France and Great Britain thus marked the destruction of the European Concert as conceived at the end of the Napoleonic hegemony. To contain Russia in 1853, Britain had to seek common ground with imperial France, already prepared to embark in such a venture. But such an unprecedented rapprochement, which was to bring a major blow to Russia's Near Eastern interests, had, nevertheless, clear implications on the international system. Napoleon III and his advisors were not against the European Concert as a tool in preserving peace and finding ways to settle major disputes among great powers, but they were anxious to reverse the so-called Vienna political order and the diplomatic defeat suffered by France in the Near East in 1840. Clearly, in 1853, it was a turning point in centre-periphery relations and a major security dilemma: to preserve the Vienna order as it was meant to leave the Ottomans at the mercy of tsar Nicholas I; to resist Russia's projects for the Ottoman Empire meant to contain Russia in European affairs and thus redefine the core of the international system.

'Nous avons sur les bras un homme malade - gravement malade' . . . . . . .

It is in these terms that tsar Nicholas I perceived the Ottoman Empire in 1853 (CRPLGCT, 1854, p. 877). His image of the Ottomans was actually not very different from that of the British, French, and Austrian statesmen of the same period of time. It suggested the idea that "Europe had political and moral obligations to manage the Ottoman collapse" (FRARY; KOZELSKY, 2014, p. 4). Despite the long life of this perception, it cannot serve as a satisfactory definition of the 'Eastern Question'. In the reading of Winfried Baumgart (1999), prominent historian and editor of primary diplomatic sources on the Crimean War, the "Eastern Question" is "the aggregate of all the problems connected with the withdrawal and the rollback of the Ottoman Empire from the areas which it had conquered since 1354 in Europe" (BAUMGART, 1999, p. 3-4). No doubt, this is a definition in which the European dimension is essential. It is also a distant echo of J. A. R. Marriott's (1917) vision: "The primary and most essential factor in the problem is [...] the presence, embedded in the living flesh of Europe, of an alien substance. 
That substance is the Ottoman Turk" (MARRIOTT, 1917, p. 3). The Ottomans, as well as the Russian Empire, were excluded from the European order as it was settled by the 1648 system of treaties. Winfried Baumgart, as many other historians, pinpoints the beginning of the 'Eastern Question' in the internationalization of the Greek rebellion during the 1820's. Thus, he does not pay much attention to the contribution of the $18^{\text {th }}$ century to this international problem. Some other scholars located the 'Eastern Question' in a broader geopolitical scenery. For instance, the historian Dimitri Kitsikis (2002) conceptualized what he called the intermediary region, which was located between the very core of the international system and the very margins of it. Eastern and South-Eastern Europe, including Russia, Turkey and Greece are considered by Kitsikis to be part of this geopolitical depiction (KITSIKIS, 2002, p. 99-116). Recently, Jacques Frémeaux (2014) also used geographical and political instruments in defining the 'Eastern Question', regarded as a conglomerate (FREMEAUX, 2014, p. 12) and not as a homogeneous ensemble.

The 'Eastern Question', as a concept, operates within a fundamental distinction between the centre and the periphery of the international system. An asymmetrical relationship is established between the two categories. The centre tends to dominate the periphery, as well as the intermediary region. On this layer of analysis, one would have in mind the writings of the much-regretted Edward Said (2003). He argued that in western academic tradition, the 'geographical Orient' is connected to an imaginary Orient, which is subject to invention, distortion and narrative colonization (SAID, 2003, p. 99). According to Said (2003), it is power that manipulates most of these representations. It is power that distributes a specific geopolitical conscience over the 'Orient' in academic and public life that nullifies all contact with reality with respect to Eastern or Near Eastern peoples and societies. Such interpretation is not built upon a critique formulated in Soviet Communist style. It actually aims at fighting against the oblivion of facts, as Georges Corm points out, which can explain in a meaningful way, violence and political change in the Balkans and the Middle East. To sum up Corm's perspective, it is the European narcissism and will to intervene that are mostly overshadowed in the study of the Ottoman-European encounters (CORM, 2002, p. 10-13).

Other contributions have also to be taken into account when defining the 'Eastern Question'. Albeit well known for his in-depth social history of the Ottoman Empire, Halil Inalcik (2006) also turned his attention towards political and international history. As one would expect, the patriarch of the Ottoman studies is not very comfortable when using a cliche like the 'Eastern Question'. However, he refers to the 'so-called Eastern question' when he touches upon the subject of the Russian annexation of Crimea at the end of the $18^{\text {th }}$ century. Inalcik (2006) wrote: "The new situation was labelled in European diplomacy as the Eastern Question, showing Western concern to preserve the Ottoman Empire, considered necessary for the European balance of power" (INALCIK, 2006, p. 113). In this particular case, Inalcik (2006), an international scholar of Turkish descent, shows a milder criticism towards the label put forward by the European chancelleries. That is to say that when European powers express concern over the Ottoman rollback, the 'Eastern Question' has a less malign connotation. Inalcik (2006) states that the solution to the 'Eastern Question' was postponed until 1856 on western religious grounds, thus admitting that the phenomenon existed. 
Nonetheless, Inalcik (2006) denounces vigorously what he considers to be the reduction of the Ottoman Empire to "the conditions of a semi-colony of the Western powers" (INALCIK, 2006, p. 118). In the same fashion, the historian Cemal Kafadar (1998) labelled the 'Eastern Question' as a European question: "its responses were not necessarily based on Eastern realities". However, Kafadar admits the idea that "the impact of Europe, whether military, diplomatic or economic worked only in tandem with internal factors" (KAFADAR, 1998, p. 70). The criticism of the 'Eastern Question' as a historical concept was also fuelled by what certain historians described as the imperial turn in historiography (MIKHAIL; PHILLIOU, 2012, p. 721745). But the revival of the imperial dimension in the study of international history had a boomerang effect, especially with respect to South-Eastern Europe and the Near East in their relation with the 'Eastern Question'. Firstly, because there was also an Ottoman orientalism (MAKDISI, 2002, p. 768796). Secondly, not only that the imperial turn did not dislocate the national grand narratives of the past in the former territories of the Ottoman Empire (meaning that the sociological reality of nationalism could not be replaced with imperial nostalgia), but it fomented a reflection on other imperial polities of the modern times and on the ways in which global rivalry rose among them and why they collapsed.

In this asymmetrical relationship between centre and periphery, was the latter deprived of all means in order to play a role in the stability of the former? The answer to this question is not very simple to give. The historian Edward Ingram, referring to the Vienna order, cut the Gordian knot by pointing out that "The core [of the Vienna system] reposed in equilibrium only because it exported to the periphery its previously bellicist style [meaning that of the Napoleonic era]" (INGRAM, 2002, p. 225). Thus, Ingram states that "the Vienna System would last as long as it ignored [...] what happened in the Ottoman Empire" (INGRAM, 2002, p. 217). He actually considers that the Ottoman Empire and Persia "formed the Vienna system's operational core" (INGRAM, 2002, p. 206) - an idea that did not get the attention it deserved in the field of international history. In a critical article about the application of the so-called concert norms in the context of the Eastern affairs, Korina Kagan (1997) numbered four major features of what some scholars might consider to be a kind of security culture after 1815: the first one refers to "individual moderation, self-restraint and the forfeit of unilateral gains"; the second one evokes the path of "multilateralism and mutual consideration" in the management of crisis; the third one takes into consideration the will of all the "members of the club" not to separate from each other in the moment of decision. The last commitment would have imposed on the great powers "the avoidance of mutual threats and shows of force" (KAGAN, 1997, p. 18-19). If real, how effective these norms were in the context of the 'Eastern Question'? Korina Kagan (1997) draws rightfully the conclusion that "the Concert was a weak and ineffective institution that did not significantly constrain state behaviour" (KAGAN, 1997, p. 55). Following the same logic as Korina Kagan (1997), but based on a more refined scholarship on the Russian case, the historian Matthew Rendall (2000) reopens the debate on concert effectiveness during the Greek war for independence. He analyses how Russia behaved during that crisis and sheds light on the functioning of the European Concert and of its presumed norms outside the purely European arenas. Rendall (2000, p. 87 ) argues that "while the Concert of Europe embodied principles and norms, however, it lacked rules and procedures 
for putting them into effect". Regarding the European Concert's involvement in the 'Eastern Question', Rendall (2000) notes: "Crucially, it was never clear whether its principles [of the European Concert] applied to the Ottoman Empire" (RENDALL, 2000, p. 87). To put it in a French realist's words, as Jean-Baptiste Duroselle (1984) may be described, "can one agree that the European Concert prevented wars or the absence of wars - caused by another factors - allowed the Concert to exist" (DUROSELLE, 1984, p. 279)? To be more precise, some of the reactions with respect to the European Concert also derived from a certain religiosity which distorted Paul W. Schroeder's (1986) meaningful hypotheses (SCHROEDER, 1986, p. 1-26) about multilate- ralism in the $19^{\text {th }}$ century. Too much focus on systemic explanations in order to feed current European federalist grand narratives blurred the complex motivations that stood behind great power behaviour in various interna- tional contexts. Controversies on Schroeder's (1986) works also arose from his own findings, as Matthew Rendall (2000) rightfully pointed out. On one hand, Schroeder (1986) seems to have the intentions of an idealist in the field of diplomatic history. On another hand, he presents his thesis with the luci- dity of the most pessimistic realist.

The heritage of the $18^{\text {th }}$ century and why it matters

The decline of the Ottomans in world affairs started only when the Habsburgs and the Romanovs put forward a strategy of territorial expansion towards the line of the Danube and created powerful networks of clients within the sultan's possessions. In conjunction with the Iranian threat and the Russian appetite for late crusade and expansion into Asia and the Caucasus, the porous Ottoman frontiers have been continuously under siege from the end of the $17^{\text {th }}$ century. Thus, the risk for the Balkans, which was the first territory conquered by the Ottomans at the beginning of their expansion towards the Catholic world (GEORGEON, 2005, p. 31), was paramount. And because significant resources had to be directed towards the European possessions of the sultan, the growing Russian and Austrian threat paved the way for the slow political awakening of the Arab speaking communities of the Ottoman Empire that exploded in the $19^{\text {th }}$ century. While Austria was a pillar of European order, Russia started to play an international role only after tsar Peter the Great put an end to Sweden's imperial ambitions. This particular moment had tremendous consequences, as the vacuum of power that appeared in the region had to be filled somehow. Besides this aspect, there was something else: it was the slow destruction of the Westphalian order imposed by France in the $17^{\text {th }}$ century with the help of Sweden in order to counter the Habsburg universal ambitions (SCHNAKENBOURG, 2011, p. 237-254). As we will show further on, the Ottomans were the indirect beneficiaries of this particular international order. That is to say that any serious threat to it had the potential to raise security concerns on the Bosporus. Once the ball has been set rolling in this direction, the Ottomans proved not to be in position to stop it. They were dragged into a spin that had long term consequences to their international position. However, the transformations of the international politics were not sudden and the Ottomans were by no means isolated.

In the eve of modernity, the French diplomacy, which was the most dynamic of the modern times, invented a way in which the Ottoman Empire could be integrated into the wider European balance of power. This was 
not the result of some strident conception or of a short-term ambition, but of a solid and of a sharp vision that passed the test of time. While the French were accused of betraying the Christian faith by relying on the Ottomans in order to fulfil their political interests, the French defended themselves by revealing how much the capitulations granted to them by the sultan improved the situation of the Catholic pilgrims and merchants in the lands of the Infidels. Nonetheless, the French-Ottoman rapprochement was built upon a long and generally predictable Bourbon-Habsburg antagonism (BERENGER, 2003, p. 297-329). And, for the French, the main purpose was in the $17^{\text {th }}$ century to inaugurate a balance of power within the Holy Roman Empire that fitted their security needs. A formal alliance between the French and the Ottomans was never formed, but, the quick de facto alliance at the time of François I was followed by a long-lasting political relation between the two entities. However, setbacks occurred as the French tried to use what looked like unlimited human and material resources of the Ottomans in order to create diversions against the Habsburgs. The Ottoman responses to the French demands were formulated, as one can imagine, according to their own security agenda. But to take into consideration only the fact that the French were looking for an ally of circumstance at Constantinople would not explain entirely what was behind the French position and it would not give us a real insight into the initial stages of the 'Eastern Question'. Actually, the French grand strategy included alongside the Ottoman Empire, Sweden, Poland and to a certain extent, Hungary. Thus, les alliances de revers represented a compound of relations of exceptional value. The French diplomacy not only endeavoured to create diversions against Austria, but also contributed significantly in fastening the ties among these allies at the periphery of the international system. It was also a condition that had to be met in order the grand strategy to survive. In the context of Russia's rise in world affairs in the first half of the $18^{\text {th }}$ century, France took the relation with its junior Eastern partners on a different level: the creation of a long buffer zone, stretching from the Baltic to the Mediterranean was envisaged. It was multilateralism at its best in the $18^{\text {th }}$ century. Among the three allies, the Ottoman Empire was the strongest and the richest one and it remained as such even after its crushing defeat at Vienna in 1683. This particular confrontation with the Habsburgs, in which the Poles mingled as well on the side of the Habsburgs under Rome's instigation, only turned the Ottoman political system north of the Danube (composed of Transylvania, Wallachia, Moldavia and the Crimean Khanate) more fragile, but not yet on the point of collapsing. However, the Ottomans were extremely far from their main chain of fortresses, supply lines and human resources. At the extremities of their Christian tributary states, control was difficult to maintain. It would have implied, on the long run, the redefinition of the state and of its central administration in order to fully intervene in these far-flung regions and dominions. But such plans were never advanced. Nevertheless, threats that occurred in other corners of the empire had to be dealt with too and Constantinople suited best the task of scrutinizing both North and South. Hence, what was difficult to achieve for the Ottomans, it was also for the Habsburgs. It meant a difficult control of the lands lost by the Ottomans even if inhabited by Christian populations. The Christian tributary states were ready to accept Habsburg rule, if situation occurred, but only after recognition of their full political autonomy and status within the Holy Roman Empire. The Habsburgs never agreed to such a concession. Thus, Ottoman rule was 
preferred by these intermediary actors and a true Danube Monarchy never saw the day, even after the conquest of Transylvania.

Despite the Russian involvements in Sweden and Poland and the Russian-Austrian rapprochement after the death of Peter the Great, the French system at the borderlands of Europe preserved itself well in the first half of the $18^{\text {th }}$ century. The less known treaty between Russia and the Ottoman Porte concluded at Pruth (1711), and the famous treaty of Belgrade (1739), proved that the Ottoman Empire was a relevant regional actor. Moreover, it showed that the problems of core and periphery could not be treated separately. The first treaty included a provision upon which Russia would find herself at war with the Ottomans if she would invade Poland again. The contribution of France to this agreement was not small. It was the French, using her envoys and several intermediaries on the battlefield, that prevented any hesitation of the Ottomans on advancing such a regional strategy. It was meant furthermore to tie a weak state like Poland to the more powerful and more organised Ottoman Empire. Moreover, it gave hope to the French that the Westphalian arrangements will be protected from a revisionist power like Russia. The second treaty, negotiated by Louis de Villeneuve, the French ambassador at Constantinople, went hand in hand with the Ottoman moderate victory over the Austrian forces. It recognized the Ottoman authority over all Walachia and Moldavia and left the Russians, the allies of Austria during this war, with no territorial gains after a rather good campaign. Not only that the French interceded with the opposing parties, but officially guaranteed the final settlement. Despite the fact that no formal provision about Poland was inserted in this particular treaty and that the alliance between Russia and Austria was still in place, the Ottomans notified the Francophile members of the Polish nobility that Russian violations of Polish territory would set the case for an Ottoman military intervention. Thus, the Ottoman interest in Polish affairs was clear, even if not simply altruistic. It also implied that the Ottomans get a share of the foreign influence in Polish affairs. And they had the back of the French for it for the sake of preserving as much as possible of what remained of the Westphalian order.

Almost thirty years of peace between the Ottomans and the Europeans passed since the negotiations of Villeneuve. To say that the Ottoman absence from the battlefields during the Seven Years War was a mistake it would not be true (AKSAN, 2012, p. 165-195). Nevertheless, the new context deserves more attention from the historians. And it is not only the fact that the Russians developed new combatting techniques and acquired glory by entering Berlin that must be pointed out, but also the relative isolation in which the Ottomans fell in Europe during this period of time. Moreover, the conclusion of the famous alliance between France and Austria in 1756 opened the door to a massive geopolitical transformation in Eastern Europe. What undermined the Sublime Porte's position was that France had to guarantee Austria against any aggression, including that of the Ottomans. It was true that the Habsburgs extended after 1739 their peace treaty with the Ottomans, but the fact that the sultan was not excluded in the mutual French-Austrian agreement made a negative impression at Constantinople. When the Russians (the allies of Austria, and par ricochet, of France against Prussia), spread the fake news of the French abandonment of their well-known policy towards the East, the Ottomans became dominated by frustration. While it was unquestionable that the French accepted and favoured the Russian intervention against Prussia and wanted the Ottomans to remain 
neutral in this truly first world war, this was not at the expense of their influence at Constantinople. However, to believe that the Russian army was a mercenary force in a purely European war, it was a huge mistake which was made at Versailles. Russia's full recognition as a great European power was not formalised until 1779, but its influence in Europe after 1755 surpassed by far that of Peter the Great. Vergennes, the French ambassador at Constantinople, had to work hard in order to convince the Ottomans not to disturb the march of the Russian army through the polish lands. It was difficult for the French ambassador to be credible after encouraging the Ottomans to observe every move of the Russians in the region (LEANCA, 2019: 128).

The consequences of the Seven Years War for France, which was the friendliest Christian Power towards the Ottomans, were catastrophic. Not only that France lost Canada, but, because of its military defeats in Europe, it was not in position to support Sweden, Poland and the Ottoman Empire, if the situation would have demanded it. In the second half of the $18^{\text {th }}$ century, all Eastern periphery of the international system fell gradually under the influence of Prussia, Austria and especially Russia (SCOTT, 2001, p. 249-250). Sweden managed to find its internal balance and resisted outside pressure on its political elites, but Poland was partitioned, which destabilised the whole region from the Baltic to the Mediterranean. It was evidence to the brutal change within the international system during the second half of the $18^{\text {th }}$ century, but this was not all. As Paul W. Schroeder rightfully pointed out, the 'engulfing' of the Ottoman Empire had implications on great power politics which surpassed by far the polish question, to which it was much connected (DAVISON, 1996, p. 180; SCHROEDER, 1994, p. 20).

Two notable Ottoman initiatives have to be mentioned in the context generated by the Seven Years War. The first one was the natural attraction the Ottomans found in the Prussian star for its victories against Austria and France, as well as for its struggle against Russia. The second one was the Ottoman interest in the Polish affairs. The war that the Ottomans decided to make against Russia in 1768 had the purpose of establishing a shared influence in Poland with the other powers. The Prussian temptation was not only a failure but the first step towards a new evolution that influenced considerably the fate of the 1768-1774 war. It was the fact that Frederic II used the Ottoman proposal for an alliance in order to determine Catherine II to conclude a mutual assistance treaty between Russia and Prussia (SCOTT, 1977, p. 153-175). The Austrians would have been isolated by such an agreement. The treaty that came into existence also named areas of interest for Prussia and Russia. It meant free hand for Russia in what Prussia considered territories of no interest for her. Moreover, one has to take into account that there was no general treaty in Europe after the Seven Years War but two treaties which were concluded separately and where Russia was not present. Thus, she had free hand to choose what suited her interests better. In other words, Russia saw its influence recognized in the 'broader Middle East' before it was truly effective. It was the clear difference between European and non-European affairs that the Russian diplomacy actually validated and to which she remained much attached thereafter. And this is where the concept of 'Eastern Europe' and its cousin the 'Near-East' truly derive from. Thus, the 'Eastern Question' originated not only from an old cultural and religious root, but also from the age of Enlightenment and of its two most illustrious representatives. It is ironical that it came straight from a binding agreement in 1764 between Catherine 
II of Russia and Frederic II of Prussia in which the Ottoman Empire was not even mentioned (LEANCA, 2019, p. 146).

In the war that followed between Russia and the Ottoman Empire, Prussia chose to tolerate the Russian expansion towards the south, if the Russian armies were to be successful. It thus paved the way for obtaining Catherine II's support for the partition of Polish lands. Austria had no choice but to participate in this massive geopolitical revolution. Vienna chose to abandon the idea of supporting the Ottomans, which was advocated by France, her ally in the West. For the Habsburgs, it was the only less expensive mean of minimizing the rapprochement between Prussia and Russia, and thus to save the very fragile balance of power in the Holy Roman Empire between the two German significant dynasties. The malfunctioning of the Ottoman supply line, the success of Orlov's expedition in Eastern Mediterranean, and the massive disobedience in the Ottoman military ranks during the 1768-1774 campaign made all the rest in order to facilitate the Russian epoch-making victory. Moreover, driven by hostility towards Prussia, Austria encouraged Catherine II Greek mesmerizing project, thus fomenting partition schemes of the sultan's domain. It becomes obvious why the Russian ambitions grew bolder in the Near-East. The annexation of Crimea by Russia (1783) was certainly a bigger blow to the Ottoman Empire than the Austrian annexation of Bukovina (1775). But they were not the only ones. By the treaty of Kuchuk-Kainardji (1774), the Ottomans were forced to agree that the Russians can 'speak' in the interest of the principalities of Moldavia and Wallachia. Thus, it appeared a form of coimperium in this bordering area which had incalculable consequences for the construction of peace in the region and in Europe, in general. The fiscal obligations of these two Christian provinces towards the Porte were to be rationalised, which paved the way for a polizeistaat and cameralist Russian policy in European Turkey. From this time onwards, the battle of the Russians with the Ottomans stretched over the forms of civilisation, technical achievements and sanitation. As shown in the historiography of the problem (DAVISON, 1976, p. 463-483), it is not true that Russia obtained by this treaty the right to protect all the orthodox living in the Ottoman Empire. However, as Vergennes observed, by inserting in an international treaty the obligation to protect Christians (AMAE-FRANCE-CADN, 1774), the Ottomans deprived themselves of fundamental elements of sovereignty at a time when a clear separation between internal and external juridical regimes was rising. By obtaining the right to interfere in the governance of the two principalities, which were fully part of the Ottoman Empire, a powerful diplomatic tool was to be put in the hands of the Russian diplomacy until the Crimean war.

Under the leadership of Vergennes, the French diplomacy found a very interesting solution in order to bring more stability to the Near Eastern affairs. While Austria's oriental ambitions were put in check by the French alliance, Russia had to be forced to restrain itself in a different fashion. It was by virtue of her status as a guarantor power of the Holy Roman Empire, alongside France, Austria and Prussia that Russia had to filter her policy at Constantinople. As a consequence of this situation, Russia agreed to provide explanatory interpretations of some provisions included in the treaty of Kuchuk-Kainardji. Thus, in the context of negotiating what became later the agreement of Teschen (1779) for the Holy Roman Empire, the Ainali-Kavak convention was signed. In both cases, the French had a crucial role. Certainly, France was not able to prevent the Russian annexation of Crimea 
because the French statesmen judged the mission impossible without the support of the British Royal Navy. After the independence war in North America and despite Vergennes's openings at London on this specific matter, such a move was impossible to foresee. However, Vergennes succeeded in stopping the Ottomans from reacting to the Crimean crisis and threatened the Austrians with the break of the alliance if they would not give up plans to annex Moldavia and Wallachia. But after the conclusion of the French-Russian treaty of 1787, Russia was tied as never before to Europe. It also meant access for the Russian and Polish goods to the Marseille markets, as well as benefits from attracting the formidable French commercial network in the Ottoman Empire towards the Black Sea coastline sales counters. With such advantages for an economy with limited cash flow, a war with the Ottoman Empire would have been useless for the Russians (LEANCA, 2019, p. 230). It was actually the Sublime Porte that nullified this sophisticated approach by declaring war to Russia in 1787. Only the risk of a continental war (in the context of entente between Prussia and England over the Netherlands) and the outbreak of the French Revolution saved the Ottomans from ceding to Russia more than the Yedisan. If the European affairs would not have turned violent, the Ottomans would have been completely wiped out from the defensive line of the Danube by the Austrian and Russian forces.

While the French revolution opened up a new era in international politics, it did not change much in the geopolitics of the Ottoman Empire. The end of the French-Austrian alliance, as well as the disappearance of Poland (1795), favoured the revival of the French-Ottoman classical political relation (FIRGES, 2017, p. 47). But the initiatives of the French revolutionaries at Constantinople needed time. What once was the powerful ottoman army needed reform and long-term training. In 1797, the Ionian Islands were occupied by France, but the French-Ottoman proximity was of no use for the sultan. This time, the blow to the Ottoman sovereignty came unexpectedly from the French themselves. Napoleon, driven by Talleyrand's projects to bring havoc in Britain's economy, invaded Egypt in 1799 and, shortly after, entered Syria (LENTZ, 2012, p. 84). While the Ottomans managed partially to drive back the French, they were in no better position internationally. The French pushed the Ottomans into the arms of the Russians with which they even concluded a treaty of alliance (MOURAVIEFF, 1954, p. 16). Moreover, the Ionian Islands passed from the hands of the French to the hands of the Russians, thus stimulating the latter's appetite for the geopolitics of the Mediterranean. However, there can be no definitive judgement of Napoleon's Near Eastern policy. Once he became the master of Europe, the Ionian Islands re-entered among the French possessions and Poland reappeared on the map of Europe. In such extraordinary context, the Ottomans shifted sides and returned to their traditional anti-Russian policy. War between Russia and the Porte followed soon, but its fate depended on Napoleon's moves. The French emperor left the impression that he would leave room to Russia in the direction of the Danube after encouraging the Ottomans to resist tsar Alexander's occupation of Moldavia and Wallachia (PURYEAR, 1951: 266). Napoleon already controlled much of what once was Poland and, therefore, tsar Alexander regarded as justified the presence of his armies on the line of the Danube. With the growing mistrust between Russia and France, such a settlement could not pass the test of time. The fact that the Ottomans, by the treaty of Bucharest (1812), ceded half of Moldavia to Russia may have been regarded as foolish by those who were aware of Napoleon's preparations to 
invade Russia. But when the Russian contribution to the defeat of French imperialism became obvious, the Ottomans found themselves in a rather correct position in relation to Russia. In other words, for the Ottomans, the 1812 arrangement was painful and useful in the same time.

From the Vienna order to the Crimean system: the last revival of the Ottoman Empire and the origins of its dissolution

The Vienna order occupies a special place in the history of international relations. It is considered to be the beginning of an almost forty years peace in Europe and the main chronological predecessor of the European integration policies. However, the aura surrounding the Vienna settlement should not restrain historians from analysing in a critical fashion the period in question and the dangers that existed in Europe in the aftermath of $\mathrm{Na-}$ poleon's fall. One can trace the origins of the bloody French-German rivalry from this particular moment (LENTZ, 2013, p. 160). In short, the Vienna arrangement was actually less visionary than many of its apologists think. Nonetheless, one should admit that after decades of violence, war and coercion in the name of liberty, peace was finally achieved in Europe. Great Britain and Russia were the main guarantors of the new order. The first power dominated the sea and the second one dominated the land. At first glance, the Ottomans benefited from this era of relative calm and detente. But their absence from the crucial negotiations at Vienna, as it was the case during the diplomatic preliminaries of the Seven Years War, could not be beneficial for their security. The period of time between the fall of Napoleon and the outbreak of the Crimean War reveals the ambiguity in which the Ottomans found themselves in relation to Europe.

The Greek crisis was brought on the table of the European diplomats in a very unusual way. At its beginnings, it was strictly perceived as an internal issue of the Ottoman Empire. The key leaders of the Greek revolution, at least at the moment of its outbreak, were based in Russia. It goes without saying, particularly in the legitimist atmosphere of Restoration Europe, that tsar Alexander had no choice but to disavow any connection with them and their ambitious plans. Count Capodistrias, tsar's minister of Foreign Affairs, who was of Greek descent, had to leave office. In fact, the Russian position in the Concert of Europe was considered at Saint-Petersburg more important than exercising open protection for the pro-Russian orthodox factions throughout the Ottoman Empire. Thus, despite the massive sympathy for the Greek cause, Russia took no military action against the Porte in the first years of the rebellion. The Greek issue did not become a true European affair until 1823 when Lord Strangford, the British ambassador at Constantinople, advocated the idea of an armistice between the conflicting sides. His action was followed by the recognition of the Greeks as belligerents. The British tried in this way to control as much as they could the political emancipation of the Greeks and the likely internationalisation of this purely Ottoman internal conflict.

To reinforce its position, the British government sent Wellington, the hero that put down Napoleon, in a mission at Saint-Petersburg in 1826 in order to discourage a Russian unilateral military intervention against the 
Ottomans. But Wellington was an unskilled diplomat. Count Nesselrode, a giant of diplomacy, convinced the illustrious British envoy to sign an agreement which allowed Russia to take action against the Ottomans with or without the participation of Great Britain. Needless to say, this bilateral arrangement was exactly the opposite of what the British statesmen had hoped for. Instead of restraining Russia and tying it down to the British line of conduct, it opened the door to her unilateral military intervention in the Ottoman Empire (COWLES, 1990, p. 688-720; BFSP, 1828, p. 629-639) and crushed the idea of consensus in the European Concert on the Greek issue. Moreover, it paved the way for the admission of the French in the negotiations ahead that were to take place precisely at London.

If the British and the Austrians opposed the use of coercive measures against the Ottomans, the French had a different approach to the crisis. Paris saw in the very unlikely self-restrain of Russia an opportunity to redefine the Vienna system according to its interests. Furthermore, it was a good chance to mediate between Great-Britain and Russia on a wide range of subjects relevant to international politics. In 1828, when it became clear that the Ottomans will not accept an European solution to the Greek question, tsar Nicholas I decided to make use of force precisely on the basis of the 1826 agreement, which was never denounced. While France could not bring into open her project of redrawing her north-eastern border (LEANCA, 2020), she obtained nevertheless in 1830 the diplomatic support of Russia for the annexation of the ottoman port of Algiers. Thus, besides the idea of compensating the French for their moderation, tsar Nicholas I manoeuvred skilfully in order to put pressure on the British presence in the Mediterranean. The British statesmen admitted that during the Greek crisis, they became the tools of Russia' (INGRAM, 1979, p. 49). However, the British defeat on the Near Eastern playground should not be overestimated. Closer as never before to Constantinople in September 1829, the Russian army halted its advance. The decision may have been justified from the military standpoint, but it also had a strategic and diplomatic motivation. The closest advisors of tsar Nicholas I convinced him that the advantages of maintaining the Ottoman Empire in Europe were superior to its rollback (KERNER, 1937, p. 287). On top of that, Russia was not isolated in Europe and Greece was freed. Nesselrode judged wisely to consider only minor territorial compensations in the aftermath of hostilities, which contradicted the idea of a Russian masterplan to swallow European Turkey. Nevertheless, the nature of the Russian-Ottoman treaty of Adrianople that followed the war was bilateral, not multilateral. That is to say that no collective guarantee was yet applied to the Ottoman Empire. Such a guarantee concerned only the newly created state of Greece. In other words, Russia preserved its special place in the coloured economy of the Ottoman foreign affairs. According to Nesselrode, Russia could use in Europe different principles of diplomatic action compared to those practiced in the Near East. On top of that, no French-British collaboration was yet possible on the muddy waters of the 'Eastern Question', which added more flavour to the epoch-making success of the Russian diplomacy in the autumn of 1829.

But the dominant position of Russia in the Near Eastern affairs was far from being indestructible. The unpredictable fall of Charles $\mathrm{X}$ in $1830 \mathrm{de}-$ 
tached France from Russia, thus opening a new era in Ottoman-European encounters. The creation of the Belgian state and the Polish revolution, no matter how peculiar they were, added new ingredients to the everlasting rivalry between powers at Constantinople. France sought a rapprochement with the Saint-James cabinet in order to counter what seemed to be, according to the liberal press, tsar's unaccountable and encroaching policies upon Europe and the Ottoman Empire. At first glance, the ties between France and Great-Britain seemed to have an effect on the Near Eastern affairs. But a true alliance between the two most liberal governments of Europe did not emerge from this special relation. The British closed their eyes to the annexation of Algiers, but they perceived the Entente Cordiale as a tool of containing France (BULLEN, 1974, p. 7). As for the Orleanist political elites, they had no reason to tie down their views on foreign affairs to those expressed on the other side of the Channel. The first Egyptian crisis (1833) did not show much of this divergence between the two powers; the Russian-Ottoman treaty of Unkiar-Iskelessi, concluded after the French mediation between Muhammad Aly and the Ottomans over Syria, placed London and Paris more or less on the same attitudinal line. By contrast, the second Egyptian crisis (1839) that posed an existential threat to the Ottoman Empire forced England to find common ground with Russia in order to discourage France from supporting the aggrandizement schemes of Muhammad-Aly at the expense of the sultan. As a result of Palmerston's ideas, the British gave a severe blow to France's Near Eastern policy and fomented in this way what we call the Rhine crisis (BROPHY, 2013). It was enough evidence to demonstrate the inextricable relation between the centre and the periphery of the international system.

The position of tsar Nicholas I needs to be explained in order to shed light on the international situation of the Ottomans at this stage. Russia was regarded at London and Paris as a power that imposed in 1833 unilaterally to the Ottomans an unfair agreement that had implications for the future of the balance of power in Europe. The bottom line of such formidable accuse was the following one: the Straits had to be kept opened to the tsar's military fleet but close for the warships of the maritime powers. According to this interpretation, it was in these conditions that Russia guaranteed the Ottoman territorial integrity in case of an Egyptian assault. Contrary to this reading of the treaty of Unkiar-Iskelessi, the Russian side never had such intentions. Actually, as revealed by the publication of key documents from the Russian archives, Nesselrode intended to prevent the entry of the Royal Navy into the Black Sea, but not to transform the Ottoman Empire in a base of operations for Russia in the Mediterranean. The reason for this self-restrain was that an aggressive Russian maritime policy would have encouraged the French and British to ask the Ottomans for the same kind of treatment with respect to the Straits (HUREWITZ, 1975, p. 261-265). The Russian position in the Crimea and in the bordering regions, such as, for instance, in Moldavia and Walachia, would have been endangered by the supposed British and French military penetration of the Black Sea. It is thus easy to understand why the Straits Convention (1841) was another success, albeit the very last one, for Russia on the entrenched diplomatic battleground of the 'Eastern Question'. The Convention strictly forbade the access of 
military vessels though the Bosporus and the Dardanelles, which served very well the Russian purpose of protecting the Crimea. In conjunction with the Münchengrätz agreement with Austria (1833), Russia was able to continue alone working for the political fragmentation of European Turkey. Thus, the Straits Convention was not a guarantee for the integrity and sovereignty of the Ottoman Empire. Despite the generous introduction attached to it, it was only a document referring to the collective use of the Bosporus and of the Dardanelles. If the Straits Convention would have served a larger purpose than this particular one, as the French diplomats suggested during the preliminary phases of the Crimean crisis, it should have in the first place nullified the 'Russian system' in the Ottoman Empire that had for basis the treaty of Kuchuk-Kainardji. But it was not the case, because the British preferred to leave things as they were at Constantinople instead of embarking in some perilous adventure with no clear agenda; it would have most probably brought back the French into the matter, just as during the Greek crisis. The 1841 convention was no victory of the European Concert against Russia and no miraculous cure for solving the 'Eastern Question'. The most tangible argument in this direction is the Crimean war itself. But the tacit agreement that took place between Great Britain and Russia made believe the latter that she might be on intimate terms with the former (PURYEAR, 1965, p. 51). The reverie of tsar Nicholas I, fomented by the exchanges he had with the British statesmen at London in 1844, ended sooner than expected.

While this article does not intend to branch out into a general discussion on the origins of the Crimean War, it has to touch upon what we consider to be its two intertwined sources. The first one has to be identified in the difficulties that surrounded the reintegration of Mount-Lebanon and Syria into the Ottoman administration after Muhammad-Aly's retreat from these regions. The second one refers to the crisis generated by the 1848 revolution at Bucharest and in Hungary.

It is not arguable that Russia was suspected in the West of intending to annex the Danube provinces. And, indeed, the Russians perceived Moldavia and Walachia as a periphery, albeit exterior, of their own empire, while the maritime powers continued to look at these two provinces through the Ottoman lens. Nevertheless, a real competition between Russia and the other powers at lasi and Bucharest never truly passed the limit of secondary consular disputes. By contrast, the maritime powers, showed more interest regarding the Levantine territories of the Ottoman Empire than Russia. In fact, European projects in order to award to Jerusalem, Bethlehem and Nazareth the status of free cities have been formulated after the return of the Ottomans to Damascus (POPOFF, 1910, p. 225). Such initiatives had a departing point in the orientalist mentality of the western diplomats, as well as in the fact that the Ottoman political system did not improve after the promulgation of the Gülhane decree. Despite the fact that the 1844's massacres in Lebanon proved such a state sufficiently, it was actually no real alternative to the Ottoman rule neither in the Levantine territories, nor in Moldavia and Wallachia.

The Ottoman authority in the Levantine provinces, no matter how keen it was to assert itself as a reformed one, was trapped in a mixture of local interests combined with a set of growing aspirations expressed by the do- 
minant powers in the region. In theory, modernisation and reinforcement of sultan's authority was the common denominator of the policies of the great powers for the Middle East after 1841. But reform and other western cures for 'the sick man of Europe' served many purposes, both of internal and external significance for each of the parties involved. Besides encouraging factional conflict in order to weaken the establishment of strong local networks of power, the Ottomans had a different war to fight. They intervened in the internal organization of the Orthodox church in order to tie it down to the authority of the sultan. As a matter of fact, Ottoman bureaucrats intervened in the election and removal of the patriarchs. But weakening the Orthodox Church was also envisaged by the British, who succeeded the Russians in the Ionian Islands and who experienced the opposition in 1838 of the bearded orthodox popes on several civil reforms (FAIREY, 2015, p. 79). As expected, the Russians were unpleasantly surprised by the Ottoman appetite for reform in the affairs of the Orthodox Church and by the British intrusion in such a delicate matter. On top of that, the Russians were worried by the progress of the French diplomacy in the Middle East. A large proportion of the Maronite leaders became the clients of France and a French consulate opened its gates at Jerusalem in 1843 (BOUYRAT, 2013, p. 279-432; NEUVILLE, 1948, p. 32-34). Russia asserted itself as the protector of Orthodoxy in the Ottoman Empire and France was entitled by its capitulations to assist the needs of the Catholic clergy in the Holy Land. Such a situation did not mean that both powers were ready to support whatever claim their clients would lay to the Ottoman authorities. Native Russian clergymen were critical of the ways in which the orthodox hierarchy in the Ottoman Empire, mainly of Greek descent, understood to interact with the believers in Syria. But France had its problems too. Its protectorate was in danger to pass to the Kingdom of Sardinia. Neither one of these complications interested the Ottomans, but from the beginning of the 1840's onwards, they were slowly dragged into a complex dispute that they thought they can handle by simply using delaying tactics.

When in 1842, the Orthodox requested to repair the church of the Holy-Sepulchre, both French and Russian diplomacies reacted. If it was true that the Orthodox had an authorisation to operate on the site, it did not mean that they could carry out the task. Adolphe de Bourqueney, the French ambassador at Constantinople, opposed the plan. Under sharp criticism from the French, the Ottomans were ready to change the terms of the approval given to the Greeks. Titov, the representative of the tsar, understood well that the purpose of the French was to undermine the privileges that Russia defended in the name of the Greek clergy. The status quo would have been altered. He thought that une déclaration de droits dispatched directly from Saint-Petersburg would be enough to silence 'the Europeans' (POPOFF, 1910, p. 316). But neither the French, nor the Russians got entirely what they hoped for because the Ottomans delayed their backing to one or the other position expressed on the matter. In fact, it was not the reparation itself that was at stake, but the advantages and the potential symbolic privileges that could be added for each side after such action. Only the Ottomans could resolve the issue. However, their decision regarding the Holy Places of Christianity became harder and harder to take. The election of Kyrillos 
II on the orthodox episcopal seat of Jerusalem (KILDANI, 2010, p. 36) seem not that important at first glance, but actually increased the pressure on the Ottomans to pronounce a solution favorable to the Greeks. It was Russia that imposed this candidate and decided that the elected one must reside in Jerusalem, not in Constantinople, as previously. And if one takes into consideration the Russian sympathy for the Arab orthodox element (HOPWOOD, 1969, p. 21; KILDANI, 2010, p. 66), it becomes obvious that the Latins had to counteract somehow these movements. Rome simply gave a new life to the diocese of Jerusalem, which was up until that time only nominal, and officially appointed Giuseppe Valerga as patriarch (1847). The French government did not like the choice made by the Pope because Valerga was Sardinian (KILDANI, 2010, p. 277-280). However, the theft of the Star from Bethlehem forced the French diplomats to engage in detailed discussions with the patriarch and to set up a plan in order to improve the situation of the fathers serving the Catholic church in the Holy Land. Otherwise, the protection of the French government would have been completely useless.

The 1848 revolution only paused for a quick period of time what seemed to be initially a struggle of influences between the Russian and the French consular offices in the Holy Land. But it was soon to be discovered that it was more than that. The bottom-up political movements across Europe did not only touch upon domestic affairs, they impacted significantly on international politics. While repression and restoration of order in Europe did silence the radical spirits, it did not foster tranquillity, but a race among ambitious actors at the immediate periphery of the international system. And there was only a matter of time before redistribution of influence among the great powers in the Middle East would have a boomerang effect on Europe.

The Ottomans had to deal with the seize of power by the revolutionaries in Bucharest. But the Ottoman envoys which were appointed to judge the events on site realized that the movement was not directed against sultan's authority, but against Russia and the creatures who patronized the regime that was just overthrown (LEANCA, 2013). It goes without saying that the Ottomans did not sympathise with the ideals expressed by the Parisian style new politicians from Bucharest. Nevertheless, under the influence of the French Republic's representatives in Constantinople, Suleyman-Pacha, the representative of the sultan at Bucharest, engaged in negotiations with the new power. Such way of dealing with the 'demagogues' legitimized the movement and its criticism towards the Russian reforms undertaken in Moldavia and Wallachia since the treaty of Adrianople. In such circumstances, the tsar authorized the army to cross the border in Moldavia. Unexpectedly, Nesselrode managed to reverse the decision. According to his views, a powerful response to the crisis would have been less manageable from the diplomatic point of view. Despite the fact that the Russian forces already crossed the Russian-Ottoman border, they started to retreat after a while. But orders were countermanded again, as the evolution of events at Bucharest was considered at Saint-Petersburg impossible to solve without a military demonstration. The Ottomans had no choice but to accept a joint occupation of Moldavia and Wallachia with the Russians and to come to terms with the fact that they have to negotiate with them an agreement. But one problem remained: the Russian occupation of the principalities was not recognized at Constantinople. The maritime powers supported the re- 
sistance of the Ottomans to any attempt to drift out from the provisions of the treaty of Adrianople. But, again, the Russians did not show any signs of weakness or concern, as they considered Moldavia and Wallachia a display for their reformist and pre-revolutionary political culture.

However, the case for an international crisis was already set. The French republican diplomacy, tired of the delays of the Russians to recognize the new regime in Paris and by the violations committed against international law at Bucharest, approached the cabinet at Saint-James. While Stratford, the British ambassador at Constantinople, was closer in his position to Aupick, the French representative at the Porte, a united strategy of the maritime powers against Russia did not come into effect. The reason for this ambiguity resided in the differences between France and Great Britain with respect to the fall of the Habsburgs. The memorable and totally unexpected event had a significant impact on the Russian-Ottoman relations. The French diplomacy was less touched by the events at Vienna compared to the British. Once tsar Nicholas I ordered his troops to put an end to the Hungarian experiment, Russia found in Austria a powerful ally in order to settle her dispute with the Ottoman government over the two principalities. If Palmerston proved right on the medium term about the capabilities of Austria of preventing Russia's expansion towards the Danube, he was wrong in this regard on the short term. The Russian intervention not only produced a high number of Polish and Hungarian refugees south of the Danube (among them the leaders of the revolution), but threatened the Ottoman government with war if the asylum seekers were not handled to their respective states of origin. It is in this particular context that France and Great Britain assured for the very first time the Ottomans of their military assistance in case of war and offered protection to the refugees. Because the British squadron dropped anchor very near the Straits, Nesselrode accused Stratford that he was responsible for the violation of the 1841 convention. If the affair did not drift towards full scale war, it was nevertheless a repetition for the British and the French in case the crisis between Russia and the Ottomans turns into open hostility. Moreover, as we have mentioned at the beginning of this article, the Balta-Liman agreement (1849) did not add any other privilege to Russia with respect to Moldavia and Wallachia. Later on, in 1853, when prince Menchikov intended to get new concessions from the Ottomans, he had to return home with no tangible results, just like it happened in 1849.

General Aupick did not only watch closely the Russian occupation of Moldavia and Wallachia. He was eager to take action in order to settle the question of the Holy Places. His energic attitude has to be understood in the context of Louis-Napoleon's rise to power, which significantly revigorated the French foreign policy. Basically, the president Louis-Napoleon did not break with the principles of the Republic in terms of foreign affairs, but he was more inclined to take action in various international arenas compared to his predecessors. He was not totally against the ideals of the French Revolution, which did not mean that he sympathised uncritically with a more traditional view on France's mission in world affairs. By the same token, Louis-Napoleon criticised the Vienna settlement and envisaged to erase France's diplomatic defeat in the Near Eastern affairs in 1840. But he was not a radical reformist in terms of international politics (SOUTOU, 2009, p. 21-21). For him, concert diplomacy was a valuable instrument as long as it would keep the balance between liberal-nationalism and imperial forms of 
government. Louis-Napoleon's moderate, but firm positions were also influenced by his close contacts with the Catholiques engagés. Favouring Catholic education in France went hand in hand with Louis-Napoleon's military support to reinstall Pope Pius IX in Rome after the success of revolution in 1849. It is in this atmosphere that the initiatives of general Aupick were formulated. His official correspondence shows that he knew that raising the issue of the Holly Places would not leave Russia indifferent. But he endorsed the idea of a more general approach on the matter. His reading of the situation was also supported by Émile Botta, the French consul at Jerusalem, and by Eugène Boré, a true advocate of the Franciscan cause in the Holy Land (AMAE-FRANCE-COURNEUVE, 1850). Asking reparation for the theft of the Star from Bethlehem was not considered enough in order to calm down the Catholics at Jerusalem. Only a firm demand to the Ottoman government in order to obtain the possession of places enumerated by the capitulations was considered suitable. In the context of Louis-Napoleon's involvement in the dispute regarding the Hungarian and Polish political refugees in the Ottoman Empire, Aupick became confident in a more substantial policy respecting the rights and privileges of the Catholic Church in the Holy Land. Albeit hesitant, La Hitte, the French minister of Foreign Affairs, approved the line of conduct suggested by his representative at Constantinople. The result was the famous note presented by Aupick to the Ottoman government the $28^{\text {th }}$ of May 1850. The Russians understood with great difficulty in 1849 and in 1850 that they cannot alter the status quo. But they could not understand why France can engage in a process that can change the status quo with respect to the privileges of the Orthodox Church. Such contradictions set the path to the Crimean War.

\section{Conclusion}

The purpose of this critical tour d'horizon on preBismarkian 'Eastern Question' is to provide a framework for a broader reflection on the international system and its transformations during the modern era. It does not intent to depict the obvious rollback of the Ottoman Empire in a $19^{\text {th }}$ century Darwinist fashion, but to look at it from a multi-layered perspective. Thus, we intended to give some insights into the functioning of the 'eternal triangle', composed of the classic European powers, Russia and the Ottoman Empire. The evolution of the 'Eastern Question' can be studied from many angles. However, we privileged the French-Russian relations because both France and Russia were the undisputed pillars of modern international relations. France represented the old Westphalian order in Europe. In turn, Russia had "both a role in and a relationship to Europe" (SCHUMACHER, 2014, p. 72). And this situation led to a paradoxical and intriguing system of communicating vessels between Russia's international position and the evolution of the Ottoman Empire in its last century of existence.

On one hand, the restrain of Russia on the Near Eastern affairs after the fall of Sebastopol had a positive impact on the Ottoman affairs. It strengthened multilateralism and, in a sense, got over most of the Russian-Ottoman conflictual inheritance of the $18^{\text {th }}$ century. One has to recall the case of Moldavia and Wallachia. United in 1859 under the suzerainty of the sultan, these two principalities remained under the guarantee of the great powers. Despite the fact that their unification fuelled nationalism and crystallised statehood, the integrity and inviolability of the Ottoman 
Empire was not affected. In the reading of Napoleon III, the architect of this change, more liberty given locally was not incompatible with imperial rule, on the contrary. The emergence of the mutasharifiya regime in Lebanon was a consequence of the same approach. In a word, bottom-top and top-bottom conflict resolution mechanisms were envisaged in order to maintain the Ottoman Empire alive. Moreover, one should recall the military neutralization of the Black Sea and the debut of the full Ottoman integration in international law.

On another hand, considering the balance of power that emerged after the Crimean War, one can state that the Ottomans tied themselves to a divided Europe. The more Russia was pushed to a distant line in European affairs, the more fragile the resulting arrangements for Europe were. The Russian diplomacy did tolerate the growth of Prussia in order to weaken the Crimean system, but not to the point of undermining its return on the Near Eastern and European stage. As the chances of the Ottomans to maintain themselves in the Balkans lessened in the second half of the $19^{\text {th }}$ century, the creation of an international sub-system of states in this region grew stronger and stronger. Marginalised in world affairs by the German Empire, France and Russia became allies. Such a revolution in international politics paved the way for the last rapprochement between Constantinople and Berlin.

\section{References:}

AMAE-FRANCE-COURNEUVE. Jacques Aupick à Jean Ernest Ducos de La Hitte, 30 janvier 1850. In: Archives du Ministere des Affaires étrangères-France, Centre des Archives Diplomatiques de La Courneuve, CP Constantinople (janvier-juin 1850), vol. 303, f. 56r.

AKSAN, Virginia H. The Ottoman Absence from the Battlefields of the Seven Years War. In: DANLEY, Mark H.; SPEELMAN, Patrick J. (eds.). The Seven Years' War: Global Views. Leiden: Brill, 2012. p. 165-195.

AMAE-FRANCE-CADN. Vergennes à Saint-Priest, Fontainebleau, 16 octobre 1774. In: Archives du Ministere des Affaires étrangères-France, Centre des Archives Diplomatiques de Nantes, Fond Constantinople, Ambassade, Série A, Fond Saint-Priest. Correspondance politique, t. 49-50, f. 100101.

BAUMGART, Winfried. The Crimean War 1853-1856. London: Arnold, 1999.

BERENGER, Jean. Les vicissitudes de l'alliance militaire franco-turque (1520-1800). In: TOLLET, Daniel (dir.). Guerres et paix en Europe centrale aux époques moderne et contemporaine. Mélanges d'histoire des relations internationales offerts à Jean Bérenger, introduction by Lucien Bély. Paris: Presses de l'Université de Paris-Sorbonne, 2003. p. 297-329.

BFSP. Protocol of Conference, between the British and Russian Plenipotentiaries, relative to the Mediation of Great Britain, between the Ottoman Porte and the Greeks, 28 March 1826; Treaty between Great Britain, France, and Russia, for the Pacification of Greece, July 6, 1827. In: British and Foreign State Papers, 1826-1827, London, Harrison and Son, Lancaster Court, 1828, p. 629-639.

BOUYRAT, Yann. La France et les Maronites du Mont-Liban. Naissance d'une relation privilégiée (1831-1861). Paris: Geuthner, 2013.

BROPHY, James, M. The Rhine Crisis of 1840 and German Nationalism: Chauvinism, Skepticism, and Regional Reception. The Journal of Modern History, v. 85, n.1, p. 1-35, 2013.

BULLEN, Roger. Palmerston, Guizot and the Collapse of the Entente Cordiale. London: The Athlone Press, 1974.

CORM, Georges. L'Europe et l'Orient. De la Balkanisation à la libanisation. Histoire d'une modernité inaccomplie. Paris: La Découverte, 2002.

COWLES, Loyal. The Failure to Restrain Russia: Canning, Nesselrode, and the Greek Question, 1825-1827. The International History Review, v. 12, n. 4, p. 688-720, nov. 1990.

CRPLGCT. Correspondence Respecting The Rights And Privileges Of The Latin And Greek Churches In Turkey. London: Harrison and Sons, 1854, vol. 5.

DAVISON, Roderic H. Russian Skill and Turkish Imbecility: The Treaty of Kuchuk Kainardji Reconsidered. Slavic Review, v. 35, n. 3, p. 463-483, 1976. 
DAVISON, Roderic H. Ottoman Diplomacy and its Legacy. In: BROWN, L. Carl (ed.). Imperial Legacy. The Ottoman Imprint on the Balkans and the Middle East. New York: Columbia University Press, 1996. p. 172-199.

DUROSELLE, Jean-Baptiste. Le Concert européen. Relations Internationales, n. 39, p. 271-285, 1984.

FAIREY, Jack. The Great Powers and Orthodox Christendom. The Crisis over the Eastern Church in the Era of the Crimean War. London: Palgrave, 2015.

FIRGES, Pascal. French Revolutionaries in the Ottoman Empire. Diplomacy, Political Culture, and the Limiting of Universal Revolution, 1792-1798. Oxford: Oxford University Press, 2017.

FRARY, Lucien J., KOZELSKY, Mara (eds.). Russian-Ottoman Borderlands. The Eastern Question Reconsidered. Madison: The University of Wisconsin Press, 2014.

FREMEAUX, Jacques. La question d'Orient. Paris: Fayard, 2014.

GEORGEON, François. L'Empire ottoman et l'Europe au XIX siècle. De la question d'Orient à la question d'Occident. Confluences Méditerranée, n. 52, p. 29-39, 2005.

HOPWOOD, Derek. The Russian Presence in Syria and Palestine 1843-1914. Church and Politics in the Near East. Oxford: Clarendon Press, 1969.

INALCIK, Halil. Turkey and Europe in History. Istanbul: Eren, 2006.

INGRAM, Edward. The Beginning of the Great Game in Asia 1828-1834. Oxford: Clarendon Press, 1979.

INGRAM, Edward. Bellicism as Boomerang: The Eastern Question during the Vienna System. In: KRÜGER, Peter; SCHRÖDER, Paul W.; WÜSTENBECKER, Katja (eds.). "The Transformation of European Politics, 1763-1848": Episode or Model in Modern History ?. Münster: Lit, 2002. p. 205-225.

JELAVICH, Barbara. Russia and the Formation of the Romanian National State 1821-1878. Cambridge: Cambridge University Press, 1984.

KAFADAR, Cemal. The Question of Ottoman Decline. Harvard Middle Eastern and Islamic Review, v. 4, n. 1-2, p. 30-75, 1997-1998.

KAGAN, Korina. The Myth of the European Concert: the Realist-Institutionalist Debate and Great Power Behaviour in the Eastern Question, 1821-41. Security Studies, v. 7, n. 2, p. 1-57, 1997.

KERNER, Robert J. Russia's New Policy in the Near East after the Peace of Adrianople; Including the Text of the Protocol of 16 September 1829. Cambridge Historical Journal, v. 5, n. 3, p. 280-290, 1937.

KILDANI, Hanna. Modern Christianity in the Holy Land. Bloomington: Authorhouse, 2010.

KITSIKIS, Dimitri. Une vision géopolitique : la Région intermédiaire. Relations Internationales, n. 109, p. 99-116, 2002.

LEANCA, Gabriel. La Révolution de 1848 dans les principautés de Moldavie et de Valachie : préfiguration de la guerre de Crimée ? Revue d'histoire diplomatique, n. 2, p. 105-120, 2013.

LEANCA, Gabriel. $\grave{A}$ I'ère des empires et des nations: la France et les principautés de Moldavie et de Valachie (1711-1859), first volume (1711-1789). Istanbul : Les Éditions Isis, 2019.

LEANCA, Gabriel. Reconstruire le centre par la périphérie : le ministère Portalis et la guerre russo-ottomane de 1828-1829. In : CAHEN, Raphaël; LAURENT-BONNE, Nicolas (dir.) Joseph-Marie Portalis. Diplomate, magistrat et législateur. Aix-en-Provence/Marseille: Presses Universitaires d'Aix-Marseille/Presses Universitaires de Provence, 2020. p. 143- 152.

LENTZ, Thierry. Napoléon diplomate. Paris: CNRS Editions, 2012.

LENTZ, Thierry. Le Congrès de Vienne. Une refondation de l'Europe 1814-1815. Paris: Perrin, 2013.

MAKDISI, Ussama. Ottoman Orientalism. The American Historican Review, v. 107, n. 3, p. 768 796, 2002.

MARRIOTT, John A.R. The Eastern Question. An Historical Study in European Diplomacy. Oxford: Clarendon Press, 1917.

MIKHAIL, Alan; PHILLIOU, Christine M. The Ottoman Empire and the Imperial Turn. Comparative Studies in Society and History, v. 54, n. 4, p. 721-745, 2012.

MOURAVIEFF, Boris. L'alliance russo-turque au milieu des guerres napoléoniennes. Neuchâtel: Éditions de la Baconnière, 1954.

NESSELRODE, Count. Interpretation of Hünkâr İskelesi. The Russian Minister of Foreign Affairs, 4/16-18/30 January 1838. In: J. C. HUREWITZ (ed.), The Middle East and North Africa in World Politics: a Documentary Record, v. I. New Haven et London: Yale University Press, 1975. p. 261-265. 
NEUVILLE, René. Heurs et malheurs des consuls de France à Jérusalem aux $x_{V I I}{ }^{\mathrm{e}}$, $\mathrm{xVIII}^{\mathrm{e}}$ et $\mathrm{xIx}^{\mathrm{e}}$ siècles, Jerusalem: Azriel Printing Works, 1948.

POPOFF, Alexandre (ed.). La question des Lieux Saints de Jérusalem dans la correspondance diplomatique russe du xix ${ }^{\mathrm{e}}$ siècle, vol. I (1800-1850). Saint-Pétersbourg: Imprimerie Russo-Française, 1910.

PURYEAR, Vernon J. Napoleon and the Dardanelles. Berkley and Los Angeles: University of California Press, 1951.

PURYEAR, Vernon J. England, Russia, and the Straits Question 1844-1856. Hamden: Archon Books, 1965.

RENDALL, Matthew. Russia, the Concert of Europe, and Greece, 1821-29: A Test of Hypotheses about the Vienna system. Security Studies, v. 9, n. 4, p. 52-90, 2000.

SAID, Edward W. Orientalism, London: Penguin Classics, 2003 (first edition in 1978).

SCHNAKENBOURG, Éric. Un pied en Allemagne'. La diplomatie francaise et la présence suédoise dans le Nord de l'Empire (1648-1720). In: DESSBERG, Fréderic, SCHNAKENBOURG, Éric (dir.). Les horizons de la politique extérieure française. Stratégie diplomatique et militaire dans les régions périphériques et les espaces seconds (XVIe-XXe siècles). Bruxelles: Peter Lang, 2011. p. 237-254.

SCHROEDER, Paul W. The $19^{\text {th }}$ Century International System: Changes in the Structure. World Politics, v. 39, n. 1, p. 1-26, 1986.

SCHROEDER, Paul W. The Transformation of European Politics 1763-1848. Oxford, Clarendon Press, 1994.

SCHUMACHER, Leslie Rogne. The Eastern Question as a Europe question: Viewing the ascent of 'Europe' through the lens of Ottoman decline. Journal of European Studies, v. 44, n. 1, p. 64-80, 2014.

SCOTT, Hamish M. Frederick II, the Ottoman Empire and the Origins of the Russo-Prussian Alliance of April 1764. European Studies Review, v. 7, n. 2, p. 153-175, 1977.

SCOTT, Hamish M. The Emergence of the Eastern Powers, 1756-1775. Cambridge, Cambridge University Press, 2001.

SOUTOU, Georges-Henri. Le système européen au XIX ${ }^{\mathrm{e}}$ siècle. In: AMEIL, Gilbert ; NATHAN, Isabelle; SOUTOU, Georges-Henri (dir.). Le Congrès de Paris (1856) Un événement fondateur. Bruxelles : Peter Lang, 2009. p. 13-25. 